\title{
Firserne - befrielse eller undergang
}

\section{Hans Jørgen Thomsen}

»Det er lissom 1930

da kapitalen var på røven sidst

da sku de tjene på krig og ballade

det ser ud til man må blive socialist«

Jomfru Ane Band
Men socialister har det heller ikke let. Det klargøres med al mulig tydelighed i en netop udsendt bog fra forlaget »Politisk Revy« med titlen »Hvad kan vi vente os af firserne «. Bogen er en (glimrende!) oversættelse i udvalg af en tobindsudgivelse fra forlaget »Olle \& Wolter«, Berlin.

En februardag i 1980 har udgiveren Ulf Wolter sat tre af Tysklands (og Europas) bedste socialistiske hoveder stævne for at diskutere fremtiden med dem. Det drejer sig om trotskisten Ernest Mandel, det drejer sig om den tidligere, eksilerede DDR kommunist Rudolf Bahro, som nu er med blandt »de grønne« i BRD, og endelig drejer det sig om venstresocialdemokraten Peter von Oertzen, der har sæde i den tyske rigsdag for SPD. Resultatet er blevet en båndudskrift af den to dage lange diskussion, og »Politisk Revy« præsenterer altså så de danske læsere for væsentlige udsnit af denne diskussion.

De tre socialister er enige om een ting, nemlig at det kapitalistiske verdenssystem befinder sig i en langstrakt krise siden starten af halvfjerdserne, og at det ikke umiddelbart er til at forudsige, hvor denne krise vil føre menneskeheden hen. Længere rækker enigheden ikke. På så godt som alle andre punkter er der uenigheder mellem de tre, og ofte er der tale om grundlæggende uenigheder. Det gælder, når de forsøger at definere problemernes natur, og det gælder, når de forsøger at give løsninger på disse problemer.

Diskussionen demonstrerer måske derfor frem for alt det svaelg mellem den socialistiske intentions universalitet (nemlig alle menneskers frigørelse) og så den naesten uendelige rakke af forskellige og ofte modstridende strategier, som denne intention kan give anledning til.

\section{Universalitet og}

\section{konkret befrielse}

Lad os begynde med at tage en enkelt, aktuel sag op, som kan anskueliggøre arten af de vanskeligheder, diskussionsdeltagerne ustandseligt støder på. Et halvt år før opstanden i Gdansk, spørger diskussionsdeltagerne sig selv: »Hvem er det, der skal ændre det hele i Øst?« 
Naturligt nok spørges Rudolf Bahro først om denne sag, og Ulf Wolter spørger på baggrund af Bahros Østeuropaanalyse i »Alternativet« om hans syn på sagen, og som i mange tilfælde stilles spørgsmålet polemisk: Wolter: »..Du står jo for en model, som man en smule polemisk tilspidset kunne kalde udskiftning af eliter. Du har sagt, at vi har brug for mennesker med overskydende bevidsthed, altså den i partierne forsamlede kritiske intelligens, som må etablere en ny form for opdragelsesdiktatur for at opdrage de 'subalterne' arbejdere til uforfærdede kommunister. Det mener du, er den eneste vej, man i disse lande vil kunne komme fra den 'realiserede' til den virkelige socialisme. Jeg har mine tvivl om en socialisme 'fra oven' «. - Hvortil Bahro svarer: »..Det er rigtigt nok, at jeg ikke kan se noget udgangspunkt for en forandring i de østeuropæiske lande $\mathrm{i}$ en eller anden form for basisdemokratisk bevægelse (hvad med Solidarnósc - HJT), og det er også rigtigt nok, at jeg $\mathrm{i}$ betragtning af de erfaringer med realiteterne, jeg selv har gjort derovre, heller ikke nu ser noget udgangspunkt i basis ${ }^{1}$.

Hér er der ingen tvivl. Historien har fældet sin dom over dén analyse, som Bahro lancerer et halvt år, før skibsværftsarbejderne sætter Polen i bevægelse og opnår større politiske indrømmelser og større liberalise- ringer end det nogensinde før er set i Østeuropa.

Det bemærkelsesværdige er hér, at manden med erfaringerne tættest inde på livet tager så grundlæggende fejl, og man må derfor også spørge videre: hvor mange af de præmisser, han bygger sin analyse på, falder med den historiske dom, som de polske arbejdere har fældet over hans analyse. Ja, den mest nærliggende præmis, som falder, er naturligvis tesen om at arbejderne i Østeuropa skulle være integreret, og at reformfors $\emptyset$ g kun er mulig med baggrund i dannelsen af overskydende bevidsthed hos partikadrer. Den polske erfaring viser, at denne præmis slet og ret er forkert.

I relation til de polske erfaringer er det Mandel, der kommer nærmest, når han overfor Bahro hævder: »Jeg tror, du undervurderer tendensen til, at arbejderne, når først de store hindringer er ryddet af vejen, simpelthen ud fra deres rene dagsinteresser begynder at tage deres sag i egne hænder på bedriftsniveau. Du undervurderer den indre dynamik, som udløses, og som ikke vil kunne standse op på det rent $\varnothing$ konomiske område «. ${ }^{2}$ Altså: den ortodokse marxists fastholdelse ved arbejderklassen som revolutionens drivende subjekt har i Polen vist sig at holde stik. På trods af, at denne fastholdelse et halvt år, før begivenhederne tager fart i Polen, endnu kan

1. »Hvad kan vi vente os af firserne«, politisk revy, s. 89-90

2. op. cit. s. 97 
tage sig abstrakt ud - sammenlignet med Bahros mere sofistikerede magtanalyser af forskellige tendenser indenfor kommunistpartiet.

Uenigheden mellem Bahro og Mandel på Østeuropaspørgsmålet er et lærestykke i den gamle sandheds gyldighed, at forholdet mellem konkret og abstrakt er intrikat for en marxistisk analytik. Marxismen må tage de konkrete hændelser og bevægelser alvorligt, men den må ikke lade sig blænde af dem. Det universelle i den socialistiske frigørelsesbestræbelse må altid betyde, at tanken ikke partikulariseres, når den analyserer de sociale forhold og de sociale befrielsesbevægelser. For hurtige generaliseringer på baggrund af såkaldte empiriske iagttagelser kan betyde, at universaliteten forflygtiges, og tanken partikulariseres. Og den partikulariserede tanke udgrænser, og i diskussionen $\mathrm{i}$ »Hvad kan vi vente os af firserne « er det især arbejderklassen, der udgrænses som muligt revolutionært subjekt.«

Her stiller Bahro og Mandel sig igen op med to forskellige forståelser. Ifølge Mandel er der ingen befrielse af socialistisk tilsnit (dvs. med universelle prætentioner), der kan ske udenom arbejderklassen, og hvis man udgrænser denne som muligt revolutionært subjekt, må konsekvensen blive pessimistisk. Så kan det slet ikke lade sig gøre. Og det giver von Oertzen ham principielt ret i. Det overordnede synspunkt, at arbejderklassen er det primære revolutionære subjekt, bør ikke opgives, fordi der med senkapitalismens udvikling opstår nye problematikfelter, der relaterer sig til artens og civilisationens skæbne som sådan.

Det er imidlertid netop disse civilisationskritiske fænomener, der får Bahro til at blæse i de teoretiske dommedagsbasuner: hvis vi ikke allerede nu tager fat på at løse det $\varnothing$ kologiske problem, er helvede kort sagt løs - og så er al snak om arbejderklassens mulighed som revolutionært subjekt alligevel bragesnak. Derfor er det politiske grundproblem i dag kampen for nulvækst, og denne er der vidtgående politiseringsmuligheder i, fordi nulvækst bryder med kapitalismens grundprincip, akkumulation.

Den principielle problematik er her selvfølgelig forholdet mellem eetpunktsbevægelser og så nødvendigheden af revolutionens universelle intention: bruddet med det kapitalistiske produktions- og livsprincip som sådan. Og faren er naturligvis, at den ene og den anden eetpunktsbevægelse kan integreres i det kapitalistiske system. Kvindebevægelsen nævnes til eksempel hér, og de tre mænd er enige om, at kvindebevægelsens krav - disses enorme samfundsmæssige betydning ufortalt kan integreres $i$ et moderniseret kapitalistisk reproduktionssystem. Kvindebevægelsens krav har altså ikke i sig selv socialismens universelle omvæltningsintention. Det er de tre mænd enige om. 
Den $\varnothing$ kologiske krise har imidlertid tid ifølge Bahro fortrin blandt alle de mange »kriser«, som kapitalismens krise udløser (fra økonomiens til politikkens krise, fra mandens til kvindens krise etc.). Den $\emptyset$ kologiske krise vedrører nemlig selve eksistensgrundlaget for arten, og derfor må den løses først, og den må løses i direkte front mod arbejderklassen i de højtudviklede lande, eftersom »de arbejdende klasser i de udviklede lande indgår i den kulturelle sammenhæng, hvis fundament er den herskende kapitalistiske civilisation. $\ll^{3}$

Vi har altså hos Bahro at gøre med følgende legering: den civilisationskritiske bevidsthed, der hos Bahro kondenseres i økologispørgsmålet, udvikles under samtidig afvikling af den ortodokse teori om arbejderklassen som revolutionens subjekt. Eller vi kan også sige, at Bahro holder fast ved Lenins gamle korrektiv til den marxske klasseanalyse, da han afskrev arbejderklasserne i de højtudviklede lande som værende arbejderaristokratier.

$\mathrm{Nu}$ har der som bekendt været en del arbejderopstande i Europa også efter, at Lenin afskrev den europæiske arbejderklasse som revolutionært subjekt. Og man kan vel ikke se bort fra, at der vil komme arbejderopstande - eller slet og ret: folkelige opstande mod stat og kapital også efter af Bahro har sagt farvel til proletariatet. Det kan såmænd være vanskeligt nok at spå om, og indvendingen skal heller ikke være et spørgsmål om professionel optimisme på proletariatets vegne overfor Bahros skepsis, hvad angår proletariatets revolutionære muligheder. Sådan kan det godt af og til tage sig ud, når Mandel i »Hvad kan vi vente os af firserne « proklamerer sin tro på proletariatet.

Nej, indvendingen mod Bahro må præcist gå på et fravar af ideologikritisk problematisering af de kriseforståelser, han bygger sin fortolkning af den nuværende kapitalistiske krise samt sine emancipationsforventninger på.

Der er nemlig een ting, man må være klar over: den kapitalistiske krise bringer alle de overleverede livsog forståelsesformer i skred uden selv at levere noget alternativ. Man kan tale om, at selv om kapitalismens krise er så nogenlunde overkommelig at forklare, hvad angår dens årsag nemlig profitabilitetskrise -, så er den nærmest uoverskuelig, hvad angår mangfoldigheden af ideologiske og sociale konsekvenser.

Derfor vil krisen i første ombæring føre til en skærpet spredning af de kritiske energier og revolutionære potentialer. Utålsomheden overfor det anderledes vil tage til, fordi så stor en del af den personlige og sociale identitet er hængt op på aktiviteterne netop dét sted, hvor man har valgt at kæmpe for at skabe et tåleligt

3. op. cit., s. 
alternativ til dén destruktion af eksistentiel og social substans, som den kapitalistiske krise bevirker. Hvis man er slumstormer, får man udslæt af universitetsmarxister; hvis man er universitetsansat eller gymnasieansat marxist, kan man ikke længere kommunikere med en arbejder, og arbejderen kan omvendt ikke holde een ud etc., etc.

Kapitalismens destruktive kraft overfor sociale og personlige livssammenhænge bevirker altså både en enorm vækst i de systemkritiske energier OG en enorm vækst i spredningen af disse energiers måde at angribe eller anfægte systemet på. $\mathrm{Og}$ det betyder igen - vil jeg hævde - en uheldig tendens til ideologisk at totalisere delaspekter i kampen mod kapitalismen. Og det bliver Bahro efter min mening et for let offer for.

Jeg har ikke videnskabelig kompetence til at tage stilling til, om netop den $\varnothing$ kologiske krise er så alvorlig og fundamental, som Bahro vil gøre den til. Jeg kan have mine tvivl, men jeg kan med sikkerhed iagttage en anden ting, nemlig at Bahros synspunkter på økologispørgsmålet fører ham ind i en lang række overvejelser på andre felter, som bliver ureflekterede, fordi han underordner dem under $\varnothing$ kologiproblematikken. Bahro bliver slet og ret et offer for den partikulariserede tanke uden at være klar over, at netop partikulariseringen af tanke- og erfaringsvirksomhed er een af de første konsekvenser af den kapitalistiske krise.

Det er præcist med baggrund i den marxistiske emancipationstænknings universelle ambition, at Mandel finder en absoluterende $\varnothing$ kologisk problembevidsthed »menneskeødelæggende «: »Nulvækst betyder ikke en bedre vækst, en omfordelt og kvalitativt forbedret vækst, tværtimod betyder det konkret i marxistisk forstand, at arbejdsproduktiviteten ikke længere stiger. Og at foreslå at arbejdsproduktiviteten ikke skulle stige mere, det ville i dag være et menneskeødelæggende forslag. Det ville i bogstavelig forstand dømme en eller to milliarder til sulted $\varnothing$ den. ${ }^{4}$

Kapitalismens universelle krise og marxismens universelle frig $\varnothing$ relsesambition kræver universelle løsninger, og den grundlæggende angrebsvinkel må derfor være angrebet på det kapitalistiske produktionsprincip: profitproduktionen. Dén er det, som omfordeler det globale arbejdsprodukt således, at man i een del af verden - den største - knapt kan tilfredsstille de mest fornødne livsbehov og $\mathrm{i}$ en anden del af verden bogstavelig talt kan få kvalme af væksten.

Samtidig er det nødvendigt at tilføje, at dette ikke betyder, at marxismen og den socialistiske frigørelseskamp skulle være ude af stand til at differentiere i den kapitalistiske form for vaekst. Det kan uden videre

4. op.cit., s. 34 
vises, at den eksisterende form for udvikling af de tekniske og åndelige produktivkræfter bærer profitproduktionens kainsmærke. Det kan demonstreres i det overordnede perspektiv, men bevidstheden om det bør også sive ned i problematiseringer af - tilsyneladende - enkeltstående teknologiske innovationer. ${ }^{5}$ Det er m.a.o. ikke blot menneskeødelæggende at plædere for nulvækst. Det er også menneskeødelæggende at plædere for en videreudvikling af den foreliggende kapitalistiske teknologi, og dét betoner Mandel ikke tilstrækkeligt.

Man kan sige, at Mandel ikke tilstrækkeligt har frigjort marxismens universelle frigørelsesambition fra dén historiefilosofiske skal, som den traditionelt har skjult sig bag. Lad os se på hvordan.

\section{Universel frigørelse og traditionel historiefilosofi}

Marxismens universelle frigørelsesintention har historisk været koblet sammen med en traditionel historiefilosofi. Denne sammenkobling er i dag i krise, og den er grunden til at mange subversive kræfter har kritiseret marxismen, idet de har set denne som en modsætning til kravene om konkret befrielse hér og nu.

Tiden er inde til at frigøre kernen fra skallen, den universelle frigørelsesintention fra historiefilosofien i traditionel form. Tiden er inde til at transformere historiefilosofien til civilisationskritik. Og man må være bevidst om, at man i et sådant ærinde er oppe imod kraftige vinde. Man er oppe imod en vind, der tenderer mod at transformere civilisationskritikken til kulturkritik (Bahro) under henvisning til, at det ikke længere er muligt eller fornuftigt at acceptere en traditionel historiefilosofi - en henvisning, som iøvrigt i sig selv er helt fornuftig og tidssvarende. Og så er man på den anden side oppe imod en vind (Mandel), der gammelmandsagtigt vil hævde, at udvikling altså bare er nødvendig - og legitimere denne påstand ved at pege på den universelle frigørelsesintention.

Sagen er, at det er et traditions$L E V N$, som stiller tænkningen i dette ubehagelige dilemma - langt fra nogen objektiv nødvendighed eller uomgængelig fornuft.

Ganske vist er det sådan, at den kapitalistiske udvikling har muliggjort tanken og forestillingen om uni-

5. Jeg kan ikke demonstrere det her, da pladsen og tematikken ikke tillader det. Men jeg kan henvise til mit efterskrift til Bahr/Vahrenkamp, »Rammer for en forståelse af teknologisk udvikling under kapitalistiske produktionsvilkår«, Rhodos Studieserie, København 1976. Det er iøvrigt bemærkelsesværdigt, at det tilsyneladende stadig er meget besværligt at kritisere den kapitalistiske teknologi uden også at ville kritisere marxismen. Diverse kulturdebattører slår sig i disse år op på at problematisere kapitalistisk teknologi og marxistisk historieforståelse i samme åndedrag. Så meget mere påtrængende synes det at være at skille »kernen« fra »skallen« i marxismen. 
versel frigørelse, men det et ikke sådan, at denne forestilling skulle være stavnsbundet til den kapitalistiske udvikling. Tværtimod tyder alt på, at en fortsat historisk stavnsbinding af frigørelsestænkningen til paradigmerne for kapitalistisk udvikling og vækst i dag ville være ligeså »menneskeødelæggende « som forestillingerne om nulvækst. M.a-.o.: tanken om klodens fuldstændige gennemkapitalisering er en uhyggevækkende og selvdestruktiv utopi.

Det universelle frigørelsesperspektiv, som er marxismens alfa og omega, kan og skal altså fastholdes, uden at man behøver at fastholde dets fødselshjælper: kapitalismen. Og sådan foregår det også de facto i mangfoldigheden af de forskellige kapitalismekritikker, som udvikles i dag. Hvad ville kvindebevægelsen være uden den kapitalistisk producerede utopi om menneskelig selvbestemmelse, eller bøssebevægelsen, eller boligbevægelserne?

Og det samme kan gøres gældende internationalt. I et fjernsynsinterview, afholdt i forbindelse med hans mondæne foredragsturne i Europa, for et halvt års tid siden, konstaterede de Kissinger, at »vores « overleverede forestilling om fremskridt var blevet rystet af begivenhederne i Iran. Man kunne ikke længere regne med, at øget materiel fremgang førte til en ideologisk og politisk stabilisering af befolkningerne. Med andre ord: befolkningerne krævede, at den materielle fremgang blev koblet på deres eget udviklingsmønster og de overleverede forståelsesformer.

Derfor må der også for den tredje og fjerde verdens vedkommende kalkuleres med muligheden af industrialisering og vækst uden at denne proces forløber i dens historiskkapitalistiske form som såkaldt oprindelig akkumulation. Ja, der er på baggrund af den nuværende form for kapitalistisk vækst ikke anden mulighed end at regne med, at befolkningerne selv skal bestemme tempo og form for industriel vækst. Deri har Bahro uomtvisteligt ret: udbredelsen af den kapitalistiske form for vækst til hele kloden ville være identisk med destruktionen af selve grundlaget for eksistens.

Det er præcist denne mulighed og alt andets umulighed -, som marxistisk nødvendiggør, at frigørelsesideen kobles fra den historiefilosofiske ramme og tildeles en selvstændig værdi. Der er opbrud nok i en selvstændiggjort frigørelsesintention med universelt perspektiv, og der er selvdestruktion i at ville acceptere, at frig $\varnothing$ relse kun er mulig i kapitalistisk form.

\section{Modernitet og tradition}

De højtudviklede kapitalistiske produktivkræfter muliggør en nybestemmelse af forholdet mellem modernitet og tradition. Moderne og af irreversibel betydning er utopien om menneskelig selvbestemmelse på profane, dennesidige betingelser, og traditionelle samfundsformer kan kun udvikle sig ved at tilnærme sig 
denne utopi, som er skabt af den kapitalistiske form for modernitet.

Omvendt kan den kapitalistiske form for modernitet i dag kun tilnærme sig selvstemmelsesutopien igennem afviklingen af præcist modernitetens kapitalistiske form. Der er ikke selvbestemmelse og lykke i ligegyldighed, hjemløshed, rastløshed, adskillelse mellem arbejde og fritid, adskillelse mellem generationerne, ghettoisering af samfundsgrupperne alle disse konsekvenser af den kapitalistiske modernitetsform må afvikles, og i denne transformationsproces er der inspiration at hente $\mathrm{i}$ traditionelle samfunds- og livsformer.

Derfor må Mandels overordnede krav om frigørelse for den industrialiserede verden - nemlig fire timers arbejdsdag - suppleres med kvalitative utopier, som bl.a. kan hente inspiration i traditionelle samfundsog livsformer. Og sådan vil de uværgerligt også hænge sammen i virkeligheden i dét øjeblik, man med baggrund i produktivikræfternes nuværende udviklingsstadium begyndte at indløse 4 timers arbejdsdag. Som vi allerede kan se det i dag: samfundsgrupper, der i dag nærmer sig selvbestemmelsesutopien i deres livspraksis, henter uværgerligt inspiration og fascination i overleverede livsforståelser, som kapitalismen i dens mest avancerede form har taget livet af. Tænk bare på det tilløbsstykke, som udstillingen »De kalder os indianere « har været i Århus som i København. Det er en gold og stadig traditionelt historiefi- losofisk tænkende marxisme, der vil afsværge disse fascinationer som regressive og irrelevante.

Produktivkræfternes nuværende udviklingsstadium muligg $ø r$ de facto en differentiering i kulturarven, og til kulturarven hører også i global forstand de kulturer, som kapitalismen er i færd med at ødelægge, eller som den allerede har ødelagt. Jeg mener: vi har ikke så frygteligt mange andre steder at hente inspiration til det antikapitalistiske arbejde end i den livssubstans, som det er kapitalismens væsen at borteskamotere.

De kvantitative og kvalitative krav, som der må stilles op overfor kapitalherredømmet, hænger sammen, og det er trist for venstrefløjen, når de to perspektiver adskilles, sådan som man kan se det i Bahro-Mandel kontroversen, som løber igennem hele diskussionen $\mathrm{i} »$ Hvad kan vi vente os af firserne «. I dét dilemma løber venstresocialdemokraten Peter von Oertzen desværre for ofte af med fornuften.

Til gengæld er von Oertzen helt og holdent indfanget i legeringen universel frigørelse/historiefilosofisk ramme. Og det betyder kort sagt, at han bliver post festum-teoretiker; at han afsværger den utopiske dimension fra tænkningen og betakker sig for teoretisk at plædere for radikale valgs nødvendighed. Fremtidens fornuft ligger længere til venstre end von Oertzen. Men kontroversen mellem Mandel og Bahro viser, at der stadig er et godt stykke historisk arbejde $i$ at få den helskindet derud. 